\title{
Analgesic and anti-inflammatory activities of some transition metal schiff base complexes
}

\author{
Mele Jesmin ${ }^{1}$, M. Khairul Islam ${ }^{2, *}$, Shaikh M. Mohsin Ali \\ ${ }^{1}$ Department of Applied Chemistry and Chemical Engineering, University of Rajshahi, \\ Rajshahi - 6205, Bangladesh \\ ${ }^{2}$ Department of Applied Chemistry and Chemical Engineering, \\ Noakhali Science and Technology University, Noakhali - 3814, Bangladesh \\ *E-mail address: skhairul77@gmail.com
}

\begin{abstract}
Analgesic and anti-inflammatory activities of four transition metal complexes of a Schiff base derived from salicylaldehyde and glycine, viz. [N-salicylideneglycinato diaqua cobalt(II) dimer] $(\mathrm{SGCo})_{2}$, [N-salicylideneglycinato-di-aqua-nickel(1l)dimer] $(\mathrm{SGN})_{2},[\mathrm{~N}$-salicylideneglycinato-aquacopper(II)] (SGC) and [N-salicylideneglycinato diaqua zinc(II) dimer] (SGZ) 2 were studied in swiss albino mice. $10 \mathrm{mg} / \mathrm{kg}$ (p.o) dose for each compound were selected throughout the research work. The analgesic activity was determined by acetic acid induced writhing and tail immersion methods. All such data were compared with standard drugs at the dose of $10 \mathrm{mg} / \mathrm{kg}$ (p.o. The anti-inflammatory activity of the test compounds was determined by the carragenan induced mice paw edema inhibition method.). Analgesic and anti-inflammatory activities of the test compounds at $10 \mathrm{mg} / \mathrm{kg}$ (p.o.) were quite comparable to those of standard drugs at $10 \mathrm{mg} / \mathrm{kg}$ (p.o.). All these compounds can be considered as potent analgesic and anti-inflammatory agents.
\end{abstract}

Keywords: Analgesic activity; Anti-inflammatory activity; Schiff bases complexes; Writhing test

\section{INTRODUCTION}

Inflammation is considered as a primary physiologic defense mechanism that helps body to protect itself against infection, burn, toxic chemicals, allergens or other noxious stimuli. An uncontrolled and persistent inflammation may act as an etiologic factor for many of these chronic illnesses [1]. Although it is a defense mechanism, the complex events and mediators involved the inflammatory reaction can induce, maintain or aggravate many diseases [2]. Currently used anti-inflammatory drugs are associated with some severe side effects. Therefore, the development of potent anti-inflammatory drugs with fewer side effects is necessary. In recent years, schiff bases are widely used in formulating various types of drugs for their diversive biological activities [3-7]. The antimicrobial activities of (SGCo)2, $(\mathrm{SGN})_{2},(\mathrm{SGC})$ and (SGZ) 2 have been previously studied [8]. It has also been found that these four complexes have been successfully utilized as anticancer agents against Ehrlich Ascites Carcinoma (EAC) cells in swiss albino mice [9]. Since cancer is often associated with pathological problems, fever, inflammation, pain etc and as anticancer agents not only kill the 
tumor cells but also cure the accessory symptoms. An attempt has been made here to study the analgesic and anti-inflammatory activities of these four Schiff base complexes.

\section{MATERIALS AND METHODS}

\section{1. Chemicals}

All chemicals and reagents used to carry out the research work were of reagent grade.

\section{2. Experimental animal}

Swiss albino mice of 5-7 weeks old, weighing 25-30 gm were collected from International Centre for Diarrhoeal Disease Reasearch, Bangladesh (ICDDR'B) Mohakhali, Dhaka (Bangladesh).

\section{3. Animal care}

Mice were kept in iron cages with saw dust and straw bedding which was changed once a week regularly. Standard mouse diet (recommended and prepared by ICDDR'B) and water were given in adequate.

\section{4. Ethical clearance}

Protocol used in this study for the use of mice as animal model for research was approved by the University Animal Ethical Committee (27/08/RUBCMB).

\section{5. Synthesis of the test compounds}

The procedure for the synthesis of the test compounds was similar to that described in the literature ${ }^{[10]}$.

\section{6. Characterization}

The formation and purity of these compounds have been confirmed by taking melting points, infrared spectra, NMR and analytical data [8]. Some physical properties and analytical data of the compounds have been presented in Table 1 .

Table 1. Physical and chemical characteristics of the schiff base complexes.

\begin{tabular}{|c|c|c|c|c|c|}
\hline $\begin{array}{c}\text { Test } \\
\text { compound }\end{array}$ & $\begin{array}{c}\text { Yield } \\
\%\end{array}$ & $\begin{array}{l}\text { Physical } \\
\text { form }\end{array}$ & Solubility & $\begin{array}{c}\text { Elemental } \\
\text { analytical data, \% }\end{array}$ & $\begin{array}{l}\text { IR spectra, } \\
\mathrm{cm}^{-1}\end{array}$ \\
\hline$(\mathrm{SGCo})_{2}$ & 50 & $\begin{array}{c}\text { Brown } \\
\text { crystalline }\end{array}$ & $\begin{array}{l}\text { Ethanol } \\
\text { Methanol } \\
\text { DMSO } \\
\text { and } \\
\text { Acetone }\end{array}$ & $\begin{array}{c}\mathrm{C}=39.22(39.70) \\
\mathrm{O}=3.98(4.04) \\
\mathrm{H}=5.32(5.15) \\
\mathrm{Co}=21.57(21.69) \\
\mathrm{H}_{2} \mathrm{O}=12.78(13.23)\end{array}$ & $\begin{array}{c}1287 \mathrm{~s}(\mathrm{C}-\mathrm{N}) \\
1691-1598 \mathrm{w} \\
(\mathrm{C}=\mathrm{N}) \\
3516 \mathrm{~s}, 3442 \mathrm{~s}, \\
3296 \mathrm{~s} \\
\text { (phenolic -OH }) \\
563 \mathrm{~s}(\mathrm{Co}-\mathrm{N}) \\
500 \mathrm{~s}(\mathrm{Co}-\mathrm{O})\end{array}$ \\
\hline
\end{tabular}




\begin{tabular}{|c|c|c|c|c|c|}
\hline$(\mathrm{SGN})_{2}$ & 50 & $\begin{array}{c}\text { Greenish } \\
\text { yellow } \\
\text { crystal }\end{array}$ & $\begin{array}{l}\text { Ethanol } \\
\text { Methanol } \\
\text { DMSO } \\
\text { and } \\
\text { Acetone }\end{array}$ & $\begin{array}{c}\mathrm{C}=37.17(39.75) \\
\mathrm{O}=4.01(4.04) \\
\mathrm{H}=5.26(5.10) \\
\mathrm{Ni}=20.96(21.60) \\
\mathrm{H}_{2} \mathrm{O}=12.55(13.25)\end{array}$ & $\begin{array}{c}3600 \mathrm{w}, 3400 \mathrm{w} \\
\left(\mathrm{H}_{2} \mathrm{O}\right) \\
1640 \mathrm{~s}(\mathrm{C}=\mathrm{N}) \\
1307 \mathrm{sh}(\mathrm{C}-\mathrm{N}) \\
560 \mathrm{~s}(\mathrm{Ni}-\mathrm{N}) \\
487 \mathrm{~s}(\mathrm{Ni}-\mathrm{O})\end{array}$ \\
\hline (SGC) & 60 & $\begin{array}{l}\text { Black } \\
\text { crystal }\end{array}$ & $\begin{array}{l}\text { Ethanol } \\
\text { Methanol } \\
\text { DMSO } \\
\text { and } \\
\text { Acetone }\end{array}$ & $\begin{array}{c}\mathrm{C}=41.55(41.93) \\
\mathrm{O}=3.06(3.11) \\
\mathrm{H}=5.24(5.44) \\
\mathrm{Cu}=24.33(24.67) \\
\mathrm{H}_{2} \mathrm{O}=6.55(6.98)\end{array}$ & $\begin{array}{c}1323 \mathrm{~s}, 1303 \mathrm{~s} \\
(\mathrm{C}-\mathrm{N}) \\
1629 \mathrm{~s}, 1602 \mathrm{~s} \\
(\mathrm{C}=\mathrm{N}) \\
3566 \mathrm{sh}, 3550 \mathrm{w} \\
\left(\mathrm{H}_{2} \mathrm{O}\right) \\
585-560 \mathrm{w}(\mathrm{Cu}- \\
\mathrm{N}) \\
478 \mathrm{~s}(\mathrm{Cu}-\mathrm{O}) \\
\end{array}$ \\
\hline$(\mathrm{SGZ})_{2}$ & 50 & $\begin{array}{l}\text { White } \\
\text { crystalline }\end{array}$ & $\begin{array}{l}\text { Ethanol } \\
\text { Methanol } \\
\text { DMSO } \\
\text { and } \\
\text { Acetone }\end{array}$ & $\begin{array}{c}\mathrm{C}=38.81(38.94) \\
\mathrm{O}=3.66(3.60) \\
\mathrm{H}=4.98(5.05) \\
\mathrm{Zn}=23.38(23.57) \\
\mathrm{H}_{2} \mathrm{O}=12.31(12.97)\end{array}$ & $\begin{array}{c}1287 \mathrm{~s}(\mathrm{C}-\mathrm{N}) \\
1612 \mathrm{~s}, 1575 \mathrm{~s}, \\
1541 \mathrm{~s}(\mathrm{C}=\mathrm{N}) \\
3313 \mathrm{~s} \\
\text { (phenolic -OH) }\end{array}$ \\
\hline
\end{tabular}

\section{7. Structure of the test compounds}

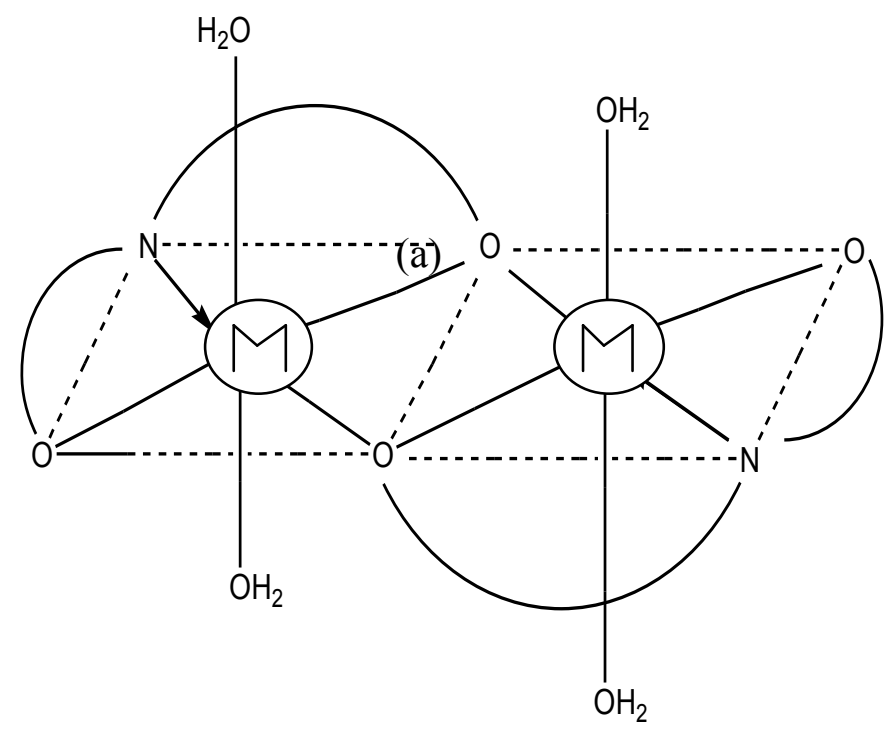

(b)

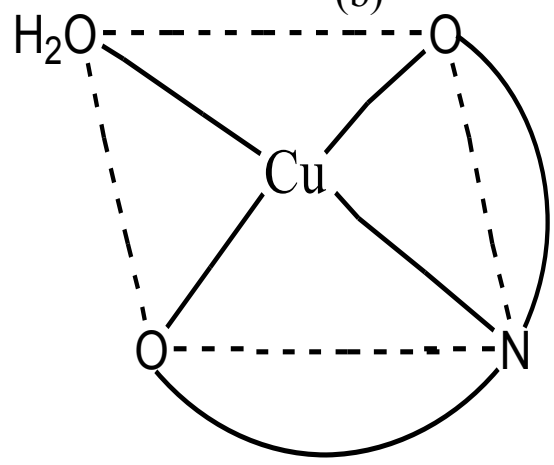

(a) Dimeric octahedral structure for Ni, Zn and Co complexes. (b) Square planar structure for $\mathrm{Cu}$ complexes.

(b) $\mathrm{M}=\mathrm{Ni}, \mathrm{Zn}$ or $\mathrm{Co}$ and the skeleton, $-\mathrm{O}-\mathrm{N}-\mathrm{O}-$ represents the following base ligand. 


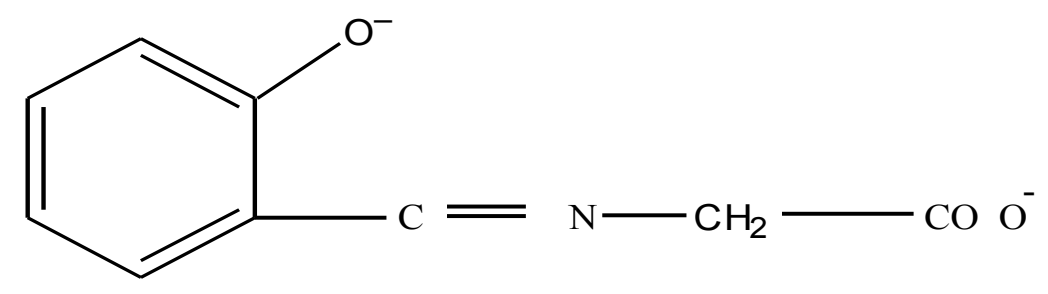

\section{8. Determination of median lethal doses $\left(\operatorname{LD}_{50}\right)$}

$\mathrm{LD}_{50}$ values were estimated by the "acute toxicity test" as described elsewhere. The test compounds were dissolved in $3 \%$ DMSO administered orally to different groups with increasing doses. Six animals were taken in each group. Mortality was determined after 24 hours of treatment. The dose, at which the $50 \%$ mice survived, was considered as $\mathrm{LD}_{50}$ value of the compound.

\section{9. Acetic acid induced writhing test for analgesic activity}

The analgesic activity of the samples was also studied using acetic acid-induced writhing model in mice. Test samples and vehicle were administered orally 30 min before intraperitoneal administration of $0.7 \%$ acetic acid but Diclofenac sodium was administered intraperitonially $15 \mathrm{~min}$ before injection of acetic acid. After an interval of $5 \mathrm{~min}$, the mice were observed for specific contraction of body referred to as 'writhing' for the next 10 min [11].

\section{10. Tail immersion test for analgesic activity}

The procedure is based on the observation that morphine like drugs selectively prolongs the reaction time of the typical tail withdrawal reflex in mice [12]. About 1-2 cm of the tail of mice was immersed in warm water kept at temperature of $55-60{ }^{\circ} \mathrm{C}$. The reaction time was the time taken by the mice to deflect their tails. The first reading was discarded and the reaction time was recorded as a mean of the next three readings. A latency period of 20 seconds was taken as complete analgesia and the measurement was then stopped to avoid injury to mice. The latent period of the tail-flick response was determined before and 0,30 , 60 and 90 min after the administration of drugs.

\section{11. Anti-inflammatory activity}

Swiss albino mice were divided into five groups of six animals each. The test groups received orally $10 \mathrm{mg} / \mathrm{kg}$ of each sample. The reference group received diclofenac sodium $(10 \mathrm{mg} / \mathrm{kg}$, p.o) while the control group received vehicle ( $1 \%$ tween 80$)$. After $1 \mathrm{~h}, 0.1 \mathrm{~mL}, 1$ $\% \mathrm{w} / \mathrm{v}$ carrageenan suspension in normal saline was injected into the subplanatar tissue of the right hind paw [13]. The paw volume was measured at $30 \mathrm{~min} .1,2,3$ and $4 \mathrm{~h}$ after carageenan injection using a micrometer screw gauge. The percentage inhibition of the inflammation was calculated from the formula:

$$
\% \text { inhibition }=\left(1-\mathrm{D}_{\mathrm{t}} / \mathrm{D}_{0}\right) \times 100
$$


Whereas $\mathrm{D}_{0}$ was the average inflammation (hind paw edema) of the control group of mice at a given time, $\mathrm{D}_{\mathrm{t}}$ was the average inflammation of the drug treated (i,e sample or reference diclofenac sodium) mice at the same time.

\section{12. Statistical analysis}

The data were expressed as mean \pm SEM. Statistical analysis was performed one-way ANOVA followed by Dunnett's multiple comparison test using sigma stat software (version 2.0, Jandel Scientific Inc. USA).

\section{RESULTS AND DISCUSSION}

$\mathrm{LD}_{50}$ values of HHP, PDH and PHP were found to be 95,80 and $100 \mathrm{mg} / \mathrm{kg}$ body weight (p.o.) respectively. To the carrageenan induced paw edema in mice, the compound showed inhibition on paw edema compared to the control group (Table 2).

Table 2. Anti-inflammatory activity of test the compounds by carrageenan induced paw edema in mice.

\begin{tabular}{|c|c|c|c|c|c|c|}
\hline \multirow[t]{2}{*}{ Group } & \multirow{2}{*}{$\begin{array}{l}\text { Dose } \\
\mathrm{mg} / \mathrm{kg} \\
(\text { p.o. })\end{array}$} & & \multicolumn{4}{|c|}{$\begin{array}{l}\% \text { inhibition of paw volume with respect to } \\
\text { control (untreated) after inoculation of } \\
\text { carrageenan. }\end{array}$} \\
\hline & & $1 / 2 \mathrm{hr}$ & $1 \mathrm{hr}$ & $2 \mathrm{hr}$ & $3 \mathrm{hr}$ & $4 \mathrm{hr}$ \\
\hline $\begin{array}{l}\text { Standard } \\
\text { (treated with } \\
\text { diclofenac } \\
\text { sodium) } \\
\end{array}$ & \multirow{5}{*}{10} & 8.12 & 14.31 & 27.37 & 51.48 & 70.29 \\
\hline$(\mathrm{SGCo})_{2}$ & & 3.48 & 9.88 & 16.32 & 28.94 & 39.66 \\
\hline$(\mathrm{SGN})_{2}$ & & 4.86 & 12.24 & 21.14 & 34.68 & 42.82 \\
\hline (SGC) & & 5.84 & 11.96 & 20.44 & 36.14 & 44.16 \\
\hline$(\mathrm{SGZ})_{2}$ & & 5.98 & 10.84 & 24.42 & 35.58 & 47.38 \\
\hline
\end{tabular}

Numbers of mice in each group were six. Results are shown as mean.

Carrageenan induced oedema has been commonly used as an experimental animal model for acute inflammation and is believed to be biphasic. The early phase (1-2 h) of the carrageenan model is mainly mediated by histamine, serotonin and increased synthesis of prostaglandins in the damaged tissue surroundings. The late phase is sustained by prostaglandin release and mediated by bradykinin, leukotrienes, polymorphonuclear cells and prostaglandins produced by tissue macrophages [14]. Since the compound inhibited paw edema induced by carrageenan in the second phase and this finding suggests a possible inhibition of cyclooxygenase synthesis by the compound and this effect is similar to that produced by non-steroidal anti-inflammatory drugs such as indomethacin, whose mechanism of action is inhibition of the cyclooxygenase enzyme. The tail withdrawal reflex times 
following administration of the compounds were found to increase. The result of the compound was comparable to the reference drug Diclofenac sodium Table 3.

Table 3. Effect of test compounds on tail immersion method of analgesic activity test in mice.

\begin{tabular}{|c|c|c|c|c|c|c|c|c|}
\hline \multirow[t]{2}{*}{ Groups } & \multirow{2}{*}{$\begin{array}{c}\text { Dose } \\
\mathrm{mg} / \mathrm{kg} \\
\text { (p.o.) }\end{array}$} & \multicolumn{4}{|c|}{$\begin{array}{l}\text { Mean latency period in second at a time of drug } \\
\text { administration }\end{array}$} & \multicolumn{3}{|c|}{$\begin{array}{c}\% \text { increase of latency } \\
\text { periodwith respect to } \\
\text { control }\end{array}$} \\
\hline & & $0 \mathrm{~min}$ & $30 \mathrm{~min}$ & $60 \mathrm{~min}$ & $90 \mathrm{~min}$ & $\begin{array}{c}30 \\
\min \end{array}$ & $\begin{array}{c}60 \\
\min \end{array}$ & $\begin{array}{c}90 \\
\min \end{array}$ \\
\hline Control & - & 046 & & & $0.58 \pm 0.12$ & - & - & - \\
\hline $\begin{array}{c}\text { Standard } \\
\text { (treated } \\
\text { with } \\
\text { morphine) }\end{array}$ & 10 & 0. & $0.80 \pm$ & $0.92=$ & $1.04=$ & 66.66 & 70.37 & 79.31 \\
\hline$(\mathrm{SGCo})_{2}$ & 10 & $0.44 \pm 0.02 *$ & $0.56 \pm 0.04$ & $0.70 \pm 0.02 *$ & $0.86 \pm 0.06^{*}$ & 16.66 & 29.63 & 48.27 \\
\hline$(\mathrm{SGN})_{2}$ & 10 & $0.42 \pm 0.06^{*}$ & $0.54 \pm 0.05^{*}$ & $0.68 \pm 0.01 *$ & $0.82 \pm 0.04 *$ & 12.5 & 25.92 & 41.37 \\
\hline (SGC) & 10 & $0.47 \pm 0.02 *$ & $0.68 \pm 0.02 *$ & $0.78 \pm 0.07 *$ & $0.90 \pm 0.11$ & 41.66 & 44.44 & 55.17 \\
\hline$(\mathrm{SGZ})_{2}$ & 10 & $0.46 \pm 0.03 *$ & $0.66 \pm 0.06^{*}$ & $0.86 \pm 0.12$ & $0.94 \pm 0.08 *$ & 37.5 & 59.26 & 62.07 \\
\hline
\end{tabular}

Numbers of mice in each group were four. Results are shown as mean \pm SEM. Where significant values are ${ }^{*} \mathrm{p}$ $<0.05$ when compared with control.

Diclofenac-sodium, the reference analgesic drug (10 mg/kg, p.o.) exhibited significant analgesic effects; while the compounds $(10 \mathrm{mg} / \mathrm{kg}$, p.o.) produced such response moderately. The tail flick method is commonly used for assessing central antinociceptive response. The method is further distinguished by their tendency to respond to the pain stimuli conducting through neuronal pathways as tail immersion mediates a spinal reflex to nociceptive stimuli [15]. Narcotic analgesics inhibit both peripheral and central mechanism of pain, while non steroidal anti-inflammatory drugs inhibit only peripheral pain [16-17]. However, the mechanism(s) behind the central analgesic response of the compound is not completely understood and may need further investigation.

Table 4 shows the effects of the compound of on acetic acid-induced writhing in mice. The oral administration of the compound inhibited writhing response induced by acetic acid. 
Table 4. Effect of test compounds on acetic acid induced writhing test in mice.

\begin{tabular}{|c|c|c|c|}
\hline Group & Doses $\mathrm{mg} / \mathrm{kg}($ p.o. $)$ & $\begin{array}{c}\text { Frequency of writhing } \\
\text { Mean } \pm \text { SEM }\end{array}$ & \% inhibition of writhing \\
\hline Control (unrteated) & - & $67 \pm 3.28$ & - \\
\hline $\begin{array}{c}\text { Standard (treated with } \\
\text { diclofenac sodium) }\end{array}$ & 10 & $15 \pm 4.15$ & 47.61 \\
\hline$(\mathrm{SGCo})_{2}$ & 30 & $35 \pm 3.74$ & 53.73 \\
\hline$(\mathrm{SGN})_{2}$ & 30 & $31 \pm 2.67$ & 44.78 \\
\hline$(\mathrm{SGC})$ & 30 & $37 \pm 4.04$ & 58.21 \\
\hline$(\mathrm{SGZ})_{2}$ & 30 & $28 \pm 5.50$ & \\
\hline
\end{tabular}

Numbers of mice in each group were four. Results are shown as mean \pm SEM. Where significant values are *p $<$ 0.05 when compared with control.

Acetic acid induced writhing response is a sensitive procedure to evaluate peripherally acting analgesics and represents pain sensation by triggering localized inflammatory response. Such pain stimulus leads to the release of free arachidonic acid from the tissue phospholipid [18]. The response is thought to be mediated by peritoneal mast cells [19], acid sensing ion channels [20] and the prostaglandin pathways [21]. The organic acid has also been postulated to act indirectly by inducing the release of endogenous mediators, which stimulates the nociceptive neurons that are sensitive to NSAIDs and narcotics [22]. It is well known that non-steroidal anti-inflammatory and analgesic drugs mitigate the inflammatory pain by inhibiting the formation of pain mediators at the peripheral target sites where prostaglandins and bradykinin are proposed to play a significant role in the pain process [23].

In addition, it was suggested that non narcotic analgesics produce their action by interfering with the local reaction to peritoneal irritation thereby reducing the intensity of apperent nervous stimulation in the acetic acid induced writhing test, a model of visceral pain [24]. Therefore, it is likely that the compound have exerted its peripheral antinociceptive action by interfering with the local reaction caused by the irritant or by inhibiting the synthesis, release and/or antagonizing the action of pain mediators at the target sites [25].

\section{CONCLUSION}

The above findings clearly demonstrated that both central and peripheral mechanisms are involved in the antinociceptive action of the test compounds. However, further studies are necessary to examine the underlying mechanisms of analgesic and anti-inflammatory effects.

\section{ACKNOWLEDGEMENT}

The authors are thankful to the department of Pharmacy, Rajshahi University, Bangladesh to provide laboratory facilities. One of the author is also thankful to UGC, Bangladesh to provide small fund to purchase chemicals. 


\section{References}

[1] Sosa S., Balicet M. J., Arvigo R., Esposito R. G., Pizza C. Altinier G. A., J. Ethanopharmacol 8 (2002) 211-215.

[2] Kumar V., Abbas A. K., Fausto N. (Eds.). Robbins and Cotran pathologic basis of disease, $7^{\text {th }}$ edition, Elsevier Saunders, Philadelphia, Pennsylvania, 2004, p. 47-86.

[3] Pandeya S. N., Sriram D., Nath G., DEclereq E., Eur J Phar Sci. 9(1) (1999) 25-32.

[4] Chen M., Phodes J., J Mol Med 74 (1996) 497-504.

[5] Islam M. R., Mirza A. M., Huda Q. M. N., Khan B. R., J Ban Chem Soc 2 (1989) 8795.

[6] Sakiyan I., Logoglu E., Arslan S., Sari N., Sakian N., Biometals 17 (2004) 115-120.

[7] Molla B. S., Rao B. S., Shridhara K., Akberali P. M., Pharmacol 55 (2000) 338-344.

[8] Islam M. N., Shahriar S. M. S., Islam M. K., Jesmin M., Ali M. M., Khanam J. A., International Letters of Chemistry, Physics and Astronomy 5 (2013) 12-20.

[9] Ali M. M., Jesmin M., Islam M. N., Shahriar S. M. S., Habib M. R., Islam M. F., Khanam J. A., ACGC Chem Res Comm 23 (2009) 13-22.

[10] Elementary Practical Organic Chemistry Part 2: Qualitative Organic Analysis; $2^{\text {nd }}$ ed., Vogel AI. 1974, 118.

[11] Gupta M., et al., J Ethnopharmacol 98 (2005) 267-273.

[12] Toma W, at al., J Ethnopharmacol 85 (2003) 19-23.

[13] Ghule R. S., Venkatnarayanan R., Thakare S. P., Jain H., Ghule P. R., J Adv. Phar Educ. Res.1 (2011) 45-51.

[14] Kaushik D., Kumar A., Kaushik P., Rana A. C., Analgesic and antiinflammatory activity of Pinus roxburghii Sarg 2012; doi:10.1155/2012/245431.

[15] Chapman C. R., Casey K. I., Dubner R., Foley K. M., Gracely R. H., Reading A. E., Pain 22 (1985) 1-31.

[16] Elisabetsky E., Amador T. A., Albuquerque R. R., Nunes D. S., Cavalho A. C. T., $J$ Ethnopharmacol 48 (1995) 77-83.

[17] Pal S., Sen T., Chaudhuri A. K. M., J Pharm Pharmacol 51 (1999) 313-318.

[18] Ahmed F., Hossain M. H., Rahman A. A., Shahid I. Z., J Ori Pharm Exp Med 6 (2006) 344-348.

[19] Ribeiro R.A., et al., Eur J Pharmacol 387 (2000) 111-118.

[20] Voilley N., Curr Drug Targets Inflamm Allergy 3 (2004) 71-79.

[21] Hossain M. M., Ali M. S., Saha A., Alimuzzaman M., Dhaka Univ J Pharm Sci. 5 (2006) 67-69. 
[22] Adzu B., Amos S., Kapu S. D., Gamaniel K. S., J Ethnopharmacol 84 (2003) 169-174.

[23] Hirose K., Jyoyama H., Kojima Y., Arzneim ittelf Forsch/Drug Res 34 (1984) 280-286.

[24] Vogel H. G., Vogel W. H., Drug Discovery and Evaluation - Pharmacological Assays. Springer-Verlag, Berlin Heidelberg 1997; 1231.

[25] Bose U., Gunasekaran K., Bala V., Rahman A. A., J Pharmacol Toxicol 5 (2010) 222228. 